Our Nature (2006)4:107-110

\title{
Tilapia-An Introduction and Prospects of its Culture in Nepal
}

\author{
C.N.R. Yadav \\ Institute of Agriculture and Animal Science \\ Rampur Campus, Rampur, Chitwan, Tribhuvan University, Nepal \\ Received: 23.07.2006; Accepted: 7.11.2006
}

\section{Introduction}

Tilapia, an African fish is used in warm water aquaculture throughout the world. It is a major source of protein in many developing countries. Although endemic to Africa its worldwide distribution has been widened due to its aquaculture potential, mainly since the 1950 s, to include much of the tropics and subtropic. (Pullin and Maclean, 1992). Two species of tilapia, Oreochromis niloticus and O. mossambicus were introduced in Nepal for the first time from Thailand in 1985 (Shrestha, 1994).

The tilapia has long been regarded as a low value-trash fish. This image, however, has changed. In fact, tilapia has been now realized as a much potential food fish commodity. Tilapia can be cultured in a wide range of aquaculture systems from simple low-density backyard ponds to highly intensive commercial farms, pens, cages and raceways. It requires simple management for its cultivation.

\section{Nomenclature}

The tilapias are recognized by the generic name cichlids now called as tilapiini. Although there exists more than 70 species, the commercially important tilapias include only 3 main genera primarily based on their reproductive behavior. Table 1 shows the genera of tilapias and some examples of important cultured species.
Oreochromis is the genus of the greatest aquacultural importance.

However, the taxonomy of this group has evolved considerably in recent years. Primarily all commercially important tilapias were grouped together under the genus Tilapia, but in the mid 1970's the mouth brooding species were separated from the species that incubated their eggs externally and were placed in the genus Sarotherodon. Around 1983, from the maternal mouth brooder species of Sarotherodon, was separated the genus Oreochromis. Consequently, an important aquacultural species such as Nile tilapia was reported as Oreochromis niloticus which was then called Sarotherodon niloticus in the literature of the late 1970 's, and prior to that it was identified as Tilapia nilotica (Popma and lovshin, 1990).

\section{Cultural Potential}

Tilapias have many aquaculture attributes. They show excellent growth rates even in low protein diets, whether cropped in natural aquatic production or provided supplementary food. They tolerate wide ranges of environmental conditions, show little susceptibility to disease and are amenable to handling and captivity. With all these advantages, tilapias have become prime domesticated species for 
fish culture (Pullin and McConnell, 1982). Nile well suited to low technology farming systems tilapia (Oreochromis niloticus) is highly in the developing world. versatile, herbivorous-microphagous feeder,

Table1. Generic nomenclature of tilapia

\begin{tabular}{lll}
\hline Genus & Reproductive behavior & Examples \\
\hline Tilapia & Substrate spawner & T. rendalli \\
A.Smith & & T. zillii \\
\hline Sarotherodon & Bi-parental mouth brooder & S. galilaeus \\
Ruppell & & S. melanotheron \\
\hline Oreochromis & Maternal mouth brooder & O. niloticus \\
Gunther & & O. mossambicus \\
& & O. aureus \\
& & O. spilurus \\
\hline
\end{tabular}

Important Species of Tilapia for Aquaculture:
A. The most widely cultured species and hybrids
1. Oreochromis niloticus
Fast growth, especially in the tropics; versatile feeder.
2. Oreochromis aureus
Fast growth; versatile feeder, cold tolerant but difficult to
seine in ponds, best grown in cages or used for hybridization.
3. Oreochromis monosex male hybrids, $O$. niloticus $\mathrm{X} O$. aureus
Fast growth, especially on pelleted feeds.

\section{B. Other cultured species}

1. Tilapia rendalli

2. Oreochromis spirulus spirulus

3. Oreochromis andersonii

4. Sarotherodon melanotheron
Macrophyte-feeders, potential for polyculture with microphagous tilapias.

Fast growth, saline-tolerant; a good grazer on epiphytic algae.

Reasonable growth and cold-tolerance.

Saline-tolerant; good growth in separate sex culture.

Source: Pullin, 1988.

Tolerance range of Tilapia to key water quality parameters

Tilapias are more tolerant than most commonly cultured freshwater fish to high water temperature, low dissolved oxygen, and high ammonia concentration (Popma and Lovshin, 1996).

Inability of tilapia to tolerate low temperatures is a serious constraint for commercial culture in temperate regions. 
The lethal low temperature for most species is $10^{\circ} \mathrm{C}$ or $11^{\circ} \mathrm{C}$, but $O$. aureus, the most cold tolerant, tolerates to $8^{\circ} \mathrm{C}$ or $9^{\circ} \mathrm{C}$.

Feeding generally ceases when water temperature falls below $16^{\circ} \mathrm{C}$ or $17^{\circ} \mathrm{C}$. Disease-induced mortalities after handling seriously constrain management below $10^{\circ} \mathrm{C}$. Reproduction is inhibited at water temperatures below $20^{\circ} \mathrm{C}$. Slow in waters of $21^{\circ} \mathrm{C}$ to $24^{\circ} \mathrm{C}$ and most frequent in waters above $25^{\circ} \mathrm{C}$. Subtropical and tropical regions with a cool season see a reduction in the numbers of fries produced during times when daily water temperature average below $24^{\circ} \mathrm{C}$.

Preferred water temperature for tilapia growth is approximately $29^{\circ} \mathrm{C}$ to $31^{\circ} \mathrm{C}$. When fish are fed to satiation, growth at preferred temperature is typically three times greater than at $22^{\circ} \mathrm{C}$. Maximum feed consumption rate at $22^{\circ} \mathrm{C}$ is only 50 to $60 \%$ as great as at $26^{\circ} \mathrm{C}$. Tilapia reportedly tolerates temperatures up to $40^{\circ} \mathrm{C}$. But stress-induced disease and mortality are problematic when temperatures exceed $37^{\circ} \mathrm{C}$ or $38^{\circ} \mathrm{C}$.

Low dissolved oxygen is usually the first water quality constraint for growth of fish in ponds. Commonly cultured species of tilapia can survive at dissolved oxygen (DO) concentrations less than $0.5 \mathrm{mg} / \mathrm{L}$. (in dawn), which is considerably below the tolerance level for most other cultured fish. Survival in water with less DO is due, in part, to their ability to extract DO from the film of water at the water-air interface when $\mathrm{DO}$ is below $1 \mathrm{mg} / \mathrm{L}$.

Tilapia seems to grow best in water that is near neutral or slightly alkaline. Growth is reduced in acidic waters (possibly due to less production of natural food organisms) but commonly cultured tilapia species survive up to $\mathrm{pH} 10$. The lethal alkaline limit is $\mathrm{pH} 11$ or greater.

Ammonia toxicity is closely correlated with $\mathrm{pH}$ and, to a lesser extent, by water temperature and DO. Ammonia toxicity is more problematic in poorly buffered ponds (alkalinity below $30 \mathrm{mg} / \mathrm{L} \mathrm{CaCO}_{3}$ ) which frequently experience afternoon $\mathrm{pH}$ levels of 9 or even 10. Ammonia is more toxic at higher temperatures; the ranges in percentage unionized form given above reflect conditions at $24^{\circ} \mathrm{C}$ to $32^{\circ} \mathrm{C}$. Low DO also increases ammonia toxicity but in fish ponds this is largely balanced by decreases toxicity produced by an increasing concentration of $\mathrm{CO}_{2}$ which lowers $\mathrm{pH}$.

\section{Sustainability of tilapia culture}

Against increasing interest in the development of tilapia farming, there are some concerns over their possible environmental impacts as exotic species. There is the fear about tilapias that derived mainly from the history of introduction of O. mossambicus that displaced the milkfish in the lagoons of Kiribati. The same was found in low waters of Fiji. Tilapia farming is now a global activity, different from its status several years ago. It is to be hoped that sufficient resources will be provided by the public and private sectors to ensure the sustainability and success of tilapia farming in developing and developed countries (Pullin et al. 1994).

\section{Prospects of Tilapia Culture in Nepal}

Though introduction of tilapia in Nepal has passed over a decade, its cultivation has not flourished. There is a general fear of displacement of indigenous fish species. Swar and Gurung (1988) found the reduction of $42 \%$ in the yield of Mystus 


\section{C.N.R. Yadav / Our Nature (2006)4:107-110}

spp. and Puntius spp. after introduction of bighead carp (Aristichthys nobilis), silver carp (Hypophthalmichthys molitrix) and grass carp (Ctenopharyngodon idella) in the Begnas lake of Pokhara valley. But biology of tilapia favors for its cultivation in Nepal. The climatic condition in hilly regions can control to an extent the over breeding activity of the fish. The minimum temperature of tolerance for Tilapia is $10^{\circ} \mathrm{C}$ - $11^{\circ} \mathrm{C}$. It cannot survive below this temperature. The physiological condition can easily be exploited in Nepalese subtropical climate to control the population of tilapia. For cultivation of the fish, coldwater bodies can be selected where temperature is rather favorable during summer for growth. Those water bodies can be used for stocking tilapia for 7-8 months and the fish would be harvested during winter months. Temperature below $10^{\circ} \mathrm{C}$ will kill the remaining fish after the harvest and there will be no fear of wild propagation. Their population will be controlled naturally. Terai region can be utilized for brood fish stocking and seed production. In this way seed production in Terai and grow out production in hilly region will be the best combination for tilapia cultivation without the fear of displacement of the indigenous fish species of the country.

For a large-scale production, sex reversed and YY- male techniques can be adopted to flourish the tilapia farming in Nepal especially in Terai region where the temperature does not fall usually below $10^{\circ} \mathrm{C}$ throughout the year. Both the technologies produce quality for that could be a good source of seed. Only male fry are produced by these techniques. The male shows better growth performance than female tilapia therefore, it is preferred.

These monosex seed production techniques should be transferred and practiced in our country for its commercial production.

\section{References}

Popma, T.J. and L.L. Lovshin 1996. Worldwide prospects for commercial production of Tilapia. Research and Development Series No. 41, International Center for Aquaculture and Aquatic Environments, Department of Fisheries and Allied aquacultures Auburn University, Alabama 36849.

Pullin, R.S.V. (Ed.) 1988. Tilapia genetic resources for aquaculture. ICLARM Conference Proceedings 16, International Center for Living Aquatic resources Management, Manila; Philippines. $108 \mathrm{p}$

Pullin, R.S.V., M.A.P. Bimbao and G.B. Bimbao 1994. World Outlook for Tilapia Farming. ICLARM contribution No. 1071, paper presented at the First International Symposium on Aquaculture, 9-11 June 1994. Boca del. Rio. Vera Cruz, MexicoPullin, R.S.V. and R.H. Lowe-McConnell (Eds.) 1982. The Biology and Culture of Tilapias. ICLARM Conference Proceedings 7, International Center for Living Aquatic Resources Management, Manila, Philippines. $432 \mathrm{p}$

Pullin, R.S.V. and J.L. Maclean 1992. Analysis of research for the development of tilapia farming an interdisciplinary approach is lacking. Netherlands Journal of Zoology 42(2-3): 512-522.

Shrestha, J. 1994. Fishes, Fishing Implements and Methods of Nepal. Smt, M.D. Gupta, Lalitpur colony, Lashkar (Gwalior), India. pp. 144

Swar, D.B. and T.B. Gurung 1988. Introduction and Cage Culture of Exotic carps and their impact on fish harvested in lake Begnas, Nepal.

Hydrobiologia 166: 277-283. 